Editorial

\title{
Seismic imaging of continents and their margins: New research at the confluence of active and passive seismology
}

Keywords:

Seismic imaging

Reflection seismology

Continental crust

Oceanic crust

Active source

Passive source

\section{Introduction}

Now that the world has well and truly crossed the threshold to the 21 st century, it seems timely to review the progress of lithospheric seismic imaging and comment on recent developments in the field. In the context of this special issue, lithospheric seismic imaging refers to any kind of seismic study that gives rise to multidimensional (2-D or 3-D) views of the Earth's interior, from the shallow crust to the base of tectonic plates. For active sources, the primary tools for delineating Earth structure include reflection seismic imaging, reflection tomography, wide-angle reflection and refraction tomography and cross-hole tomography. In cases involving modest numbers of unknowns (e.g. in 2-D), forward modelling approaches are often also used with reflection and wide-angle data. In the case of passive sources, local earthquake tomography, teleseismic tomography, ambient noise tomography, and receiver function migration are all capable of retrieving lithospheric structure.

With the notable exception of Peaceful Nuclear Explosions (Nielsen et al., 1999; Priestley et al., 1994; Ryberg et al., 1996), active source imaging is largely confined to the crust and mantle lithosphere. Its use is widespread in the exploration industry, particularly in delineating sedimentary structures favourable to hydrocarbon entrapment (e.g. Sheriff and Geldart, 1995). On a broader scale, active source imaging has been widely used to vastly improve our understanding of crustal and uppermost mantle structure and processes, and enjoys a history over many decades involving hundreds of experiments around the globe (Prodehl and Mooney, 2012; Thybo et al., 2011).

Passive source imaging, which historically has exploited seismic energy from earthquakes, is capable of elucidating structure at a variety of scales, from the shallow crust to the whole Earth (Rawlinson et al., 2010a). Compared to active source imaging, the cost of data acquisition is generally much lower, but this advantage is offset by the spatial and temporal irregularities of natural seismicity, which have a profound effect on data coverage. Although active and passive source studies are often carried out independently, it has long been recognised that potential overlaps exist, and a joint treatment of both classes of data may yield improved results compared to separate analyses. For example, both Ankeny et al. (1986) and Thurber (1983) include refraction traveltimes from explosive sources in a local earthquake tomography study. Others have combined marine airgun traveltimes and local earthquake data (Parsons and Zoback, 1997; Wagner et al., 2007) and marine airgun traveltimes and teleseismic traveltime residuals (Rawlinson et al., 2010b). In the latter case, wide-angle reflections and refractions provide good coverage of the crust, but poorer coverage beneath the Moho, whereas the teleseismic data optimally constrain the lithospheric mantle and lowermost crust, but poorly constrain the mid-upper crust. A joint inversion therefore takes full advantage of their complementary strengths.

The idea of overlap between passive and active source datasets is examined in more detail below, and is a theme that has gradually grown in prominence over the last few years at the Seismix conference series on which this special issue is based. With the advent of new theory and techniques, passive source imaging appears to be gradually encroaching on territory that has traditionally been the exclusive domain of active source seismology.

\section{The rise of passive seismic imaging}

The roots of modern passive seismic imaging of the lithosphere can be traced back to the pioneering work of Keitti Aki, who published two seminal papers in consecutive years: the first describes and implements a method for imaging 3-D structure using local earthquakes recorded in California (Aki and Lee, 1976), and the second introduces a means of exploiting relative arrival times recorded across an array from distant earthquakes to image the underlying lithosphere (Aki et al., 1977) - a technique now commonly known as teleseismic tomography. Since these pioneering studies, rapid advances in instrument technology, computing power and theoretical developments have allowed the crust and mantle to be imaged with increasing precision. In local earthquake tomography, advances over the last few decades include the use of full 3-D ray tracing accompanied by iterative non-linear inversion (Eberhart-Phillips, 1990), direct inversion for anisotropy and attenuation (Eberhart-Phillips and Henderson, 2004; Hirahara, 1988; Sanders, 1993; Shito et al., 2006), and the use of adaptive grid parameterizations (Zhang and Thurber, 2005). In regions like subduction zones, local earthquake tomography can image deep into the upper mantle (Graeber and Asch, 1999) by virtue of the favourable distribution of sources at depth. High resolution near surface imaging is also possible provided numerous sources clustered at shallow depths are available. One example of this is volcano tomography (e.g. Aloisi et al., 2002; Patane et al., 2002; Toomey and Foulger, 1989), which uses earthquakes associated with mass movement beneath active volcanoes to image shallow structures such as magma chambers and associated plumbing systems. Using this approach, resolutions of the order of a $\mathrm{km}$ or less are sometimes possible. Therefore, local earthquake tomography can offer similar 
structural constraints to those obtained by some wide-angle active source imaging experiments. However, given the irregular nature of earthquake source distribution, the need to relocate events simultaneously with structural recovery, and a lack of control on the source waveform, seismic imaging of the shallow-mid crust using local earthquakes could only ever complement, and not replace, the class of results that can be achieved using active sources.

Since its development by Aki et al. (1977), teleseismic tomography has undergone a number of advancements, including full 3-D ray tracing and iterative non-linear inversion (Rawlinson et al., 2006; Steck et al., 1998; VanDecar and Snieder, 1994), the recovery of anisotropy (Grésillaud and Cara, 1996; Plomerová et al., 2008) and attenuation (Young and Ward, 1980), the inclusion of finite frequency constraints (Ren and Shen, 2008; Yang et al., 2009) and full waveform inversion (Roecker et al., 2010). Teleseismic tomography can be performed successfully in most regions of the Earth because earthquakes are not required to be nearby. However, the near vertical incidence of impinging seismic energy and the lack of high frequencies limit the resolution that can be achieved. Furthermore, the base assumption of a good prior knowledge of the wavefront that impinges on the local model volume (e.g. by assuming a global reference model outside the model region) essentially means that as the base of the model becomes shallower, there is an increased tendency for artefacts to be mapped as 3-D structure. Nevertheless, relatively high resolution teleseismic tomography has been carried out - for example, Steck et al. (1998) achieve resolutions of the order of only a few km using data collected in New Mexico, and Xu et al. (2009) attempt to recover structure beneath the western Qaidam basin using, in some cases, station spacings of less than a $\mathrm{km}$.

The extremely high levels of detail that can be obtained using reflection seismic profiling is due to very dense sampling coupled with the rich information content of near vertical incident reflected waves, which are highly sensitive to vertical contrasts in structure. As early as the mid 1970s, it was recognised that teleseismic waves, which travel nearly vertically upwards through the lithosphere, are also sensitive to strong vertical variations in structure, such as the Moho. Teleseismic receiver functions (Langston, 1977; Owens et al., 1984; Vinnik, 1977; Zhu and Kanamori, 2000) exploit this fact by removing the source time function from the recorded teleseism to reveal a waveform that is dominated by impulses caused by reflections and mode conversions through structure beneath a receiver. Structural information can be retrieved from receiver functions in various ways, including direct inversion for 1-D shear wavespeed (e.g. Reading and Kennett, 2003) or migration of the receiver functions (Sheehan et al., 2000; Wilson et al., 2005) into model space to create a 2-D profile akin to a seismic reflection section (although not interpreted in quite the same way). The level of detail achievable is limited largely by the frequency content of teleseisms and the station spacing used, although many studies are able to image subtle small-scale variations in crustal structure (e.g. Yamauchi, 2003).

Another approach for imaging the lithosphere with teleseismic waves makes use of secondary scattered waves in the P-wave coda (Bostock et al., 2001; Revenaugh, 1995; Ryberg and Weber, 2000). Teleseismic waves which transmit through the lithosphere will eventually reflect off the free surface; these reflections can be regarded as plane wave sources that emanate energy from the surface, which will ultimately produce back-scattered energy that will be recorded. Provided sufficiently dense recording arrays are in place, the backscattered wavefield can be directly migrated into model space, in a similar manner to conventional active source reflection seismic. Forward scattered energy, as exploited in receiver functions, can also be included in such a migration process. By using dense linear arrays, it is possible to achieve high resolution images of the crust and uppermost mantle (e.g. Rondenay et al., 2001; Snyder et al., 2004; Suckale et al., 2009), although again, the frequency content of the teleseismic waves means that resolutions on-par with active source reflection profiling are not possible.

During the last decade, the advent and rapid development of virtual-source seismology - or seismic interferometry - has brought passive source imaging a step closer to being able to match active source imaging in delineating fine-scale crustal structure. Although the roots of this field were first put in place by Claerbout (1968) and others (e.g. Scherbaum, 1987), it is the more recent demonstration (Campillo and Paul, 2003; Lobkis and Weaver, 2001; Shapiro and Campillo, 2004; Wapenaar et al., 2005) of inter-station structure extracted from the cross-correlation of random or diffuse wavefields recorded by receiver pairs that has lead to such widespread application. The so-called empirical Green's function that comes from the cross-correlation is similar to what would be recorded at one receiver if the other were a source that generated a delta function signal (provided that the noise field is homogeneous about the receivers). From an imaging perspective, the deployment of a large number of receivers provides the possibility of achieving excellent data coverage that is controlled almost entirely by the array geometry. With $N$ receivers, a total of $N(N-1) / 2$ empirical Green's functions are potentially available, which means that a single large array is generally more profitable than several smaller ones.

An almost ubiquitous natural source of ambient noise that can be readily detected by seismometers comes from oceanic microseisms and atmospheric disturbances. As a result, historic seismic datasets recorded by arrays deployed to record natural seismicity have become the focus of much recent attention, because they contain previously untapped information on the Earth's lithospheric structure. The ambient noise information extracted from these datasets generally comes in the form of surface wave empirical Green's functions, and standard dispersion analysis followed by inversion for group, phase and/or shear wave velocity can be carried out to produce two and three dimensional models of the subsurface (Arroucau et al., 2010; Kang and Shin, 2006; Shapiro et al., 2005; Yang et al., 2007; Yao et al., 2006; Young et al., 2011; Zheng et al., 2008). The resolution limit of these studies is controlled by both station spacing and frequency content of the ambient noise. For oceanic noise, the highest frequencies that can be exploited are around $1 \mathrm{~Hz}$ (Huang et al., 2010; Young et al., 2011) which means that near-surface structures with scale lengths in the $\mathrm{km}$ range can be detected. As a result, imaging of economically prospective regions like sedimentary basins and geothermal fields is possible (e.g. Huang et al., 2010; Yang et al., 2011).

The use of anthropogenic noise sources such as traffic noise or vibrations from heavy machinery open up the prospect of extremely high resolution imaging owing to the availability of much higher frequencies (Curtis et al., 2006). Although it could be argued that these are in fact active sources of noise, in most cases they are preexisting and not introduced for the purposes of an imaging experiment. As such, deployments in these environments would merely take advantage of existing seismic energy, which is the default approach of passive seismic studies. By using a linear array of geophones, Nakata et al. (2011) show that it is possible to extract both body and surface waves from traffic noise in Gunma, Japan with frequencies up to $25 \mathrm{~Hz}$. From the body wave data, they are able to create a migrated reflection section with vertical resolution of the order of $10 \mathrm{~m}$. By inverting surface wave dispersion for shear wave velocity, layers less than $50 \mathrm{~m}$ thick can be discriminated. Applications of seismic interferometry for imaging in exploration is one of the new frontiers of passive seismology in the 21st century, where economic, social and environmental impacts associated with the exploration for and extraction of deep Earth resources are of great concern.

\section{New horizons in active seismic imaging}

Active source seismic imaging is a diverse field with many classes of application. It has been the progenitor of numerous developments in seismology, with a recent example being full waveform tomography 
(Pratt, 1999; Pratt and Shipp, 1999; Pratt and Worthington, 1988; Pratt et al., 1996; Sirgue and Pratt, 2004). Although in this short introductory paper we cannot hope to cover all directions that are being taken in this field, we will briefly discuss several intriguing developments that are particularly relevant to the symposium upon which this special volume is based. This includes time-lapse monitoring at $\mathrm{CO}_{2}$ storage sites, direct imaging of mineralization and the delineation of dynamic structures in the ocean using marine seismic reflection data.

In many countries throughout the world, the need for dramatic reductions in the aerial dispersion of greenhouse gas emissions from energy production facilities has been recognised. One approach to this reduction is geosequestration, in which $\mathrm{CO}_{2}$ emissions are stored below ground in geologically favourable areas, such as depleted hydrocarbon reservoirs and saline aquifers. In many regions of the world, large projects have been started to locate and rank subsurface reservoir candidates for $\mathrm{CO}_{2}$ sequestration (Lumley, 2010). Close monitoring of the subsurface during and following injection of $\mathrm{CO}_{2}$ is essential to ensure correct emplacement of fluids and no leakage to surrounding uncontained regions, which may result in undesirable effects like groundwater contamination.

The process of time-lapse seismic reservoir monitoring involves carrying out multiple repeat surveys (usually reflection profiling) using identical sources and acquisition geometries on each occasion. The issue of repeatability is crucial, with marine surveys generally considered to be more repeatable than land surveys; in the latter case, weather related and anthropogenic noise, plus velocity variations in the near surface, variations in source parameters and geophone coupling are all important factors (Pevzner et al., 2011). The challenge is then to extract the differences in the resulting images in essence to subtract the geology, remove noise effects, and illuminate the time-varying fluid flow changes in the reservoir. This is generally done using a cross-equalisation approach (Rickett and Lumley, 2001), that can involve data regridding, matched filter corrections, phase and static shifts and so forth.

Spatial imaging is often done in 2-D or 3-D, with the latter sometimes referred to as 4-D seismic to imply the time varying component (Lumley, 2001). As well as requiring accurate prior knowledge of the reflection properties of $\mathrm{CO}_{2}$, rock physics measurements of the host structure are required in order to ascertain pressure and temperature conditions and other physical variables that can affect seismic velocity and density (Lumley, 2001). The use of time-lapse seismic methods to monitor subsurface $\mathrm{CO}_{2}$ storage is on the rise, as more facilities gradually come on-line. Examples include the Otway Basin Pilot project in Australia (Urosevic et al., 2011), the Sleipner project beneath the North Sea, which began in 1996 (Chadwick et al., 2009), and the Weyburn $\mathrm{CO}_{2}$ monitoring and storage project in Canada (Preston et al., 2005).

Another active area of research involves 3D seismic reflection imaging of ore deposits in hard rock environments (e.g. Drummond et al., 1998; Eaton et al., 2003) - for example volcanic-hosted massive sulphide (VMS) deposits (Malehmir and Bellefleur, 2009), which can generate high acoustic impedance values in typical volcanosedimentary settings (Salisbury et al., 2000), or alteration zones associated with gold mineralization where crustal-penetrating shear zones intersect the surface (Goleby et al., 2004). This is a departure from the normal geophysical methods - such as electromagnetic used to delineate these structures. The processing of seismic data collected in crystalline environments is somewhat different to what is applied to data collected in regions that host hydrocarbon deposits (Milkereit et al., 1996). This is largely due to the presence of complex and heavily deformed lithological contacts which tend to behave as scatterers rather than continuous reflectors. Following prestack filtering and static corrections, typical workflows involve a prestack DMO (dip move out) correction and postack migration (Malehmir and Bellefleur, 2009). Simply applying NMO (normal move out) corrections without
DMO corrections tends not to be effective owing to the various dip geometries that are present.

VMS deposits imaged by 3D reflection seismic tend to be revealed by a diagnostic diffraction response. Milkereit et al. (2000) demonstrate via a numerical experiment that a high impedance localised ore body will produce a scattered response that varies according to its prevailing strike and dip. This finding was verified in a practical test using high frequency 3-D reflection data from the Sudbury Basin in Canada, where it was shown that massive sulphide bodies produce a diagnostic scattering response. Ongoing research into this area includes the use of P-S converted waves (Malinowski and White, 2011) to complement the conventional P reflections; early indications are that while PS reflections from the main lithological units have a lower signal to noise ratio than their PP counterparts, the PS signal is enhanced when it encounters the ore zone.

In 2003, Steven Holbrook published a paper (Holbrook et al., 2003) that heralded the dawn of what is now commonly referred to as "seismic oceanography". In this paper, they show that fine scale ocean phenomena, including thermohaline intrusions, internal waves and eddies can be successfully extracted from conventional marine reflection profiles that typically target sedimentary structures beneath the ocean floor. Previously, precursory arrivals from the ocean column that precede the primary reflection from the ocean floor were ignored, but it turns out that once the effects of the direct arrival are removed and amplitudes enhanced, a wealth of reflections related to ocean dynamics is revealed. Although marine reflection surveys are relatively expensive, many regions of the oceans - particularly continental shelves and slopes, are covered by extensive swaths of reflection lines thanks principally to the efforts of the exploration industry. In their seminal paper, Holbrook et al. (2003) exploit reflection profiles taken across the oceanographic front between the Labrador Current and the North Atlantic Current, and show that the transition between warm and cold currents is characterised by east-dipping reflectors generated by thermohaline intrusions. Since the first appearance of seismic oceanography almost a decade ago, the field has gradually expanded, with numerous applications of the technique in various parts of the world (e.g. Holbrook et al., 2009; Koenitz et al., 2008; Sheen et al., 2011).

\section{The symposium: deep seismic profiling of continents and their margins}

The 14th international symposium on "Deep seismic profiling of the continents and their margins" (aka. Seismix 2010) was held between August 29 and September 3 at Rydges Esplanade Resort Hotel in Cairns, northeast Australia. Seismix is a biennial event that provides an opportunity for seismologists and related specialists from all continents to meet and discuss advances in various forms of seismic imaging. Traditionally, the focus has been on seismic profiling acquisition, processing and interpretation, but in recent years, the conference has branched out to include various other forms of seismic imaging that can probe the crust and uppermost mantle. A total of 93 registered participants attended the conference, with a subset of these going on to the four day post-symposium field trip that examined the Palaeozoic and Proterozoic terranes traversed by a deep seismic transect acquired in 2007.

As at previous Seismix symposia, the scientific programme involved a single schedule of oral presentations and poster presentations. The main themes into which all talks and posters were divided are as follows:
- Continental evolution
- Crust and mantle
- Continental margins
- Mineral, geothermal and $\mathrm{CO}_{2}$ systems
- Seismic methods, data acquisition and modelling. 
Each of these themes was subjected to a thorough workout at the symposium. The Continental evolution theme contained a geographically diverse range of presentations, that focused on regions including south Australia, Russia, Fennoscandia, Canada, Tibet and northern Africa. Reflection seismic profiling and wide-angle tomography were the principal tools of analysis, although several multidisciplinary studies that used a number of datasets were also presented. The Crust and mantle theme tended to focus on the nature of the Moho and lithospheric mantle, and had a more even division between active and passive source studies. The Continental margins theme was very popular this year, with oral presentations spanning two days. Active margins received much more attention than passive margins, with talks and posters given on topics such as the Alpine Fault in New Zealand, the Japan subduction zone, and the San Andreas Fault system.

The Mineral, Geothermal and $\mathrm{CO}_{2}$ Systems theme attracted a number of presentations on 3D seismic reflection imaging in hard rock areas, with the focus being the detection of economically viable ore bodies. Both field examples and technical developments were discussed. There were also several papers on the monitoring of $\mathrm{CO}_{2}$ geosequestration sites and geothermal exploration. In the final theme - Seismic methods, data acquisition and modelling - the audience was treated to a variety of talks and posters which included topics such as seismic oceanography and ambient noise tomography. Two presentations were given on extracting body wave information from ambient noise, which reflects the growing potential of virtual source seismology to impinge on areas traditionally occupied by active source imaging, such as deep seismic profiling.

The Seismix 2010 symposium also featured four invited speakers who each gave 40 minute presentations. Ramon Carbonell spoke about crustal seismic studies in the Iberian Peninsula, Brian Kennett described the structure of the Australian lithosphere from a seismic perspective, Takaya Iwasaki summarised recent active and passive seismic imaging studies in the Japan region, and Richard Hobbs introduced the audience to the relatively new field of seismic oceanography.

\section{In this volume}

This volume is based on presentations given at the Seismix 2010 symposium, and follows in the tradition of special volumes produced from previous Seismix symposia (Barazangi and Brown, 1986a, 1986b; Carbonell et al., 2000; Clowes and Green, 1994; Davey and Jones, 2004; Ito et al., 2009; Klemperer and Mooney, 1998a, 1998b; Leven et al., 1990; Matthews and Smith, 1987; Meissner et al., 1991; Snyder et al., 2006; Thybo et al., 2011; White et al., 1996). It does not purport to provide a comprehensive sampling of all topics that were covered, but instead presents a relatively small selection of interesting papers in several different subject areas. A number of promised contributions from colleagues in Japan did not materialise due to the very destructive earthquake and resulting tsunami that struck near the east coast of Honshu in March 2011, which naturally focused their attention elsewhere. We wish them well as their country gradually recovers from this traumatic event.

Of the 10 papers contained in this volume, three examine various aspects of reflection seismic data processing and interpretation, two deal with new imaging techniques, and the remaining five focus on observational studies of the crust and mantle using a range of seismic data. Bongajum et al. (this volume) investigate seismic wave propagation in hard rock environments that exhibit an effective anisotropy due to small scale heterogeneity with a preferred orientation. They use numerical simulations of wave propagation to show that reverse time migration using mean $\mathrm{P}$-wave velocities will adequately migrate target reflections/diffractions to their correct location provided small scale velocity fluctuations do not exceed $5 \%$. Von Hartmann et al. (this volume) present a refined sequence-stratigraphic method that allows a selection of seismic attributes to be related to different depositional conditions when interpreting 3-D reflection seismic images of carbonate platforms. They apply the new scheme to data collected from the Molasse Basin in southern Germany, and show that they are able to discriminate between various carbonate facies within the platform. Goncharov and Nelson (this volume) examine the effects of water loading on seismic velocities obtained by marine reflection surveys. In particular they investigate the validity of using seismic interval velocities derived from stacking velocities for interpreting rock lithology, when these velocities can vary by as much as $1 \mathrm{~km} / \mathrm{s}$ due to water-induced compaction effects. They conclude that with appropriate processing and data selection procedures, seismic interval velocities can correlate reasonably closely with well measurements. They apply their approach to data collected from the Wallaby Plateau, Western Australia, and show that water loading effects make it difficult to discriminate between volcanic and sedimentary compositions in the substrate. This is in contrast to previous analyses which inferred a dominantly volcanic composition.

As noted previously in Section 2 there has been increased interest in the use of ambient noise sources for seismic imaging. The paper of Ito et al. (this volume) is one of the first to be published that demonstrates that body waves extracted from ambient noise can be used for structural imaging. In this case, autocorrelation of background noise is used to construct seismic reflection images in the northeastern Japan subduction zone. Depth migration of the autocorrelated signals show that the subducting Pacific slab is seismically transparent, whereas the mantle wedge is characterised by a reflective structure.

Many seismic images that are published today result from the solution of a large, under-determined and often highly non-linear inverse problem, and efficient yet robust solution techniques are in short supply. Roberts et al. (this volume) demonstrate the feasibility of replacing the forward solver needed by the inverse problem with a so-called "emulator" or mathematical function that mimics the output of the forward solver. This can potentially result in vastly improved compute times. The authors demonstrate the emulator approach on a joint data set comprising first-arrival seismic refraction, MT and gravity data over a diapiric salt body.

Thybo and Nielsen (this volume) present the results of a refraction and wide-angle reflection study in the Danish Basin. They successfully image a $110 \mathrm{~km}$ long E-W trending high velocity zone which they interpret to be an intrusive body of gabbroic composition, with a volume of at least $60,000 \mathrm{~km}^{3}$. 2D full-waveform inversion is also used to infer the presence of a layered transition zone around the Moho from PmP reverberations, which may be explained by magmatic intrusion along the Moho over a lateral distance of $130 \mathrm{~km}$ away from the magmatic source. They conclude that the large intrusive body must have had a substantial impact on the temperature field and may have initiated post-Permian subsidence of the Danish Basin.

Using deep crustal seismic reflection profiling, Korsch et al. (this volume) examine the structure and geodynamic framework of north Queensland, Australia. They find evidence, in the form of west dipping reflectors that offset the Moho, of a fossil subduction zone to the east of the Mount Isa Province. Another important finding is that the Greenvale and Charters Towers provinces, previously thought to be discrete provinces, may in fact be continuous in the subsurface. Kanao et al. (this volume) use both gravity data and broadband seismic data to probe the structure of the crust in East Antarctica. They find that the crustal thickness beneath the Gambursev Subglacial Mountains is between 55 and $58 \mathrm{~km}$, which contrasts with the $40-47 \mathrm{~km}$ of the surrounding region, implying that the mountain range is isostatically compensated.

Rawlinson and Fishwick (this volume) use teleseismic body waves and surface waves recorded by the WOMBAT transportable array experiment to constrain the 3-D structure of the lithospheric mantle beneath southeast Australia. They identify a major N-S oriented transition zone associated with the boundary between Proterozoic and Palaeozoic terranes at depth, and a low velocity zone extending 
to a depth of approximately $200 \mathrm{~km}$ that appears to be associated with recent Quaternary hot spot volcanism in western Victoria. Hong et al. (this volume) use a variety of seismic techniques to examine evidence for reverse activation of a paleo-rifting system in the Sea of Japan. This includes the distribution of recent seismicity, crustal anisotropy measurements from shear wave splitting, moment tensor solutions from long-period waveform inversion and the ambient stress field derived from focal mechanisms. They find that the compressional stress field and occurrence of active thrust events suggest reverse activation of palaeo-normal faults originally formed during the opening of the Sea of Japan.

\section{Acknowledgements}

The 14th International Symposium on Deep Seismic Profiling of the Continents and their Margins (Seismix 2010) was organised by Geoscience Australia, the Research School of Earth Sciences at The Australian National University, the Specialist Group in Solid Earth Geophysics of the Geological Society of Australia and IGCP559. Assistance from the Geological Survey of Queensland in organisation of the post symposium field excursion was also provided. Financial sponsorship was provided by the Geological Society of Australia and IGCP559.

\section{References}

Aki, K., Lee, W.H.K., 1976. Determination of the three-dimensional velocity anomalies under a seismic array using first $P$ arrival times from local earthquakes 1 . A homogeneous initial model. Journal of Geophysical Research 81, 4381-4399.

Aki, K., Christoffersson, A., Husebye, E.S., 1977. Determination of the three-dimensiona seismic structure of the lithosphere. Journal of Geophysical Research 82, 277-296.

Aloisi, M., Cocina, O., Neri, G., Orecchio, B., Privitera, E., 2002. Seismic tomography of the crust underneath the Etna volcano, Sicily. Physics of the Earth and Planetary Interiors $134,139-155$.

Ankeny, L.A., Braile, L.W., Olsen, K.H., 1986. Upper crustal structure beneath the Jemez Mountains volcanic field, New Mexico, determined by three-dimensional simultaneous inversion of seismic refraction and earthquake data. Journal of Geophysical Research 91, 6188-6198.

Arroucau, P., Rawlinson, N., Sambridge, M., 2010. New insight into Cainozoic sedimentary basins and Palaeozoic suture zones in southeast Australia from ambient noise surface wave tomography. Geophysical Research Letters 37, L07303 http://dx.doi.org/ 10.1029/2009GL041974.

Barazangi, M., Brown, L. (Eds.), 1986a. Reflection Seismology: The Continental Crust: Am. Geophys. Union, Geodyn. Ser., 14. 339 pp.

Barazangi, M., Brown, L. (Eds.), 1986b. Reflection Seismology: A Global Perspective: Am. Geophys. Union, Geodyn. Ser., 13. 311 pp.

Bostock, M.G., Rondenay, S., Shragge, J., 2001. Multiparameter two-dimensional inversion of scattered teleseismic body waves 1 . Theory for oblique incidence. Journal of Geophysical Research 106, 30,771-30,782.

Campillo, M., Paul, A., 2003. Long-range correlations in the diffuse seismic coda. Science 299, 547-549.

Carbonell, R., Gallart, J., Torne, M., 2000. Deep seismic profiling of the continents and their margins selected papers from the 8th international symposium on deep seismic profiling of the continents and their margins, Barcelona, Spain, 2025 September 1998 preface. Tectonophysics 329, 1-4.

Chadwick, R.A., Noy, D., Arts, R., Eiken, O., 2009. Latest time-lapse seismic data from Sleipner yield new insights into $\mathrm{CO}_{2}$ plume development. Energy Procedia 1, 2103-2110.

Claerbout, J.F., 1968. Synthesis of a layered medium from its acoustic transmission response. Geophysics 33, 264-269.

Clowes, R.M., Green, A.G., 1994. Seismic reflection probing of the continents and their margins. Tectonophysics 232, VII-IX.

Curtis, A., Gerstoft, P., Sato, H., Snieder, R., Wapenaar, K., 2006. Seismic interferometry - turning signal into noise. The Leading Edge 25, 1082-1092.

Davey, F.J., Jones, L., 2004. Special issue - continental lithosphere - papers presented at the 10th international symposium on deep seismic profiling of the continents and their margins - Taupo, New Zealand, 610 January 2003 - introduction. Tectonophysics 388, 1-5

Drummond, B.J., Goleby, B.R., Goncharov, A.G., Wyborn, L.A.I., Collins, C.D.N MacCready, T., 1998. Crustal-scale structures in the Proterozoic Mount Isa Inlie of north Australia: their seismic response and influence on mineralisation. Tectonophysics 288, 43-56.

Eaton, D.W., Milkereit, B., Salisbury, M.H., 2003. Hardrock Seismic Exploration. Society of Exploration Geophysicists, Tulsa.

Eberhart-Phillips, D., 1990. Three-dimensional P and S velocity structure in the Coalinga Region, California. Journal of Geophysical Research 95, 15,343-15,363.

Eberhart-Phillips, D., Henderson, C.M., 2004. Including anisotropy in 3-D velocity inversion and application to Marlborough, New Zealand. Geophysical Journal International 156, 237-254.

Goleby, B.R., Blewett, R.S., Korsch, R... Champion, D.C., Cassidy, K.F., Jones, L.E.A. Groenewald, P.B., Henson, P., 2004. Deep seismic reflection profiling in the
Archaean northeastern Yilgarn Craton, Western Australia: implications for crustal architecture and mineral potential. Tectonophysics 388, 119-133.

Graeber, F.M., Asch, G., 1999. Three-dimensional models of $P$ wave velocity and $P$-to-S velocity ratio in the southern central Andes by simultaneous inversion of local earthquake data. Journal of Geophysical Research 104, 20,237-20,256.

Grésillaud, A., Cara, M., 1996. Anisotropy and P-wave tomography: a new approach for inverting teleseismic data from a dense array of stations. Geophysical Journal International 126, 77-91.

Hirahara, K., 1988. Detection of three-dimensional velocity anisotropy. Physics of the Earth and Planetary Interiors 51, 71-85

Holbrook, W.S., Páramo, P., Pearse, S., Schmitt, R.W., 2003. Thermohaline fine structure in an oceanographic front from seismic reflection profiling. Science 301, 821-824.

Holbrook, W.S., Fer, I., Schmitt, R.W., 2009. Images of internal tides near the Norwegian continental slope. Geophysical Research Letters 36, L00D10 http://dx.doi.org/ 10.1029/2009GL038909.

Huang, Y.-C., Yao, H., Huang, B.-S., van der Hilst, R.D., Wen, K.-L., Huang, W.-G., Chen, C.-H., 2010. Phase velocity variation at periods of 0.53 Seconds in the Taipei Basin of Taiwan from correlation of ambient seismic noise. Bulletin of the Seismological Society of America 100, 2250-2263.

Ito, T., Iwasaki, T., Thybo, H., 2009. Deep seismic profiling of the continents and their margins - preface. Tectonophysics 472, 1-5.

Kang, T.-S., Shin, J.S., 2006. Surface-wave tomography from ambient seismic noise of accelerograph networks in southern Korea. Geophysical Research Letters 33 http://dx.doi.org/10.1029/2006GL027044.

Klemperer, S.L., Mooney, W.D., 1998a. Special issue deep seismic profiling of the continents, I: general results and new methods. Tectonophysics 286, IX-XIV.

Klemperer, S.L., Mooney, W.D., 1998b. Special issue deep seismic profiling of the continents, II: a global survey. Tectonophysics 288, VII-VIII.

Koenitz, D., White, N., McCave, I.N., Hobbs, R.W., 2008. Internal structure of a contourite drift generated by the Antarctic circumpolar current. Geochemistry, Geophysics, Geosystems 9, Q06012 http://dx.doi.org/10.1029/2007GC001799.

Langston, C.A., 1977. The effect of planar dipping structure on source and receiver responses for constant ray parameter. Bulletin of the Seismological Society of America $67,1029-1050$.

Leven, J.H., Finlaysson, D.M., Wright, C., Dooley, J.C., Kennett, B.L.N. (Eds.), 1990. Seismic Probing of Continents and Their Margins: Tectonophysics, 173. $641 \mathrm{pp}$.

Lobkis, O.I., Weaver, R.L., 2001. On the emergence of the Green's function in the correlations of a diffuse field. Journal of the Acoustical Society of America 110, 3011-3017.

Lumley, D.E., 2001. Time-lapse seismic reservoir monitoring. Geophysics 66, 50-53.

Lumley, D., 2010. 4D seismic monitoring of CO2 sequestration. The Leading Edge 29, $150-155$.

Malehmir, A., Bellefleur, G., 2009. 3D seismic reflection imaging of volcanic-hosted massive sulfide deposits: insights from reprocessing Halfmile Lake data, New Brunswick, Canada. Geophysics 74 http://dx.doi.org/10.1190/1.3230495.

Malinowski, M., White, D., 2011. Converted wave seismic imaging in the Flin Flon mining camp, Canada. Journal of Applied Geophysics 75, 719-730.

Matthews, D.H., Smith, C. (Eds.), 1987. Deep Seismic Reflection Profiling of the Continental Lithosphere: Geophys. J. Royal Astr. Soc., 89. 447 pp.

Meissner, R., et al. (Ed.), 1991. Continental Lithosphere: Deep Seismic Reflections: Am. Geophys. Union, Geodyn. Ser., 22. 450 pp.

Milkereit, B., Eaton, D.W., Wu, J., Perron, G., Saisbury, H., Berrer, E., Morrison, G., 1996. Seismic imaging of massive sulphide deposits: Part II, reflection seismic profiling. Exploration Geophysics 91, 829-834.

Milkereit, B., Berre, E.K., King, A.R., Watts, A.H., Roberts, B., Adam, E., Eaton, D., Wu, J., Salisbury, M.H., 2000. Development of 3-D seismic exploration technology for deep nickel-copper deposits - a case history from the Sudbury basin, Canada. Geophysics 65, 1890-1899.

Nakata, N., Snieder, R., Larner, K., Tsuji, T., Matsuoka, T., 2011. Shear-wave imaging from traffic noise using seismic interferometry by cross-coherence. SEG Expanded Abstracts 30 http://dx.doi.org/10.1190/1.3627505.

Nielsen, L., Thybo, H., Solodilov, L., 1999. Seismic tomographic inversion of Russian PNE data along profile Kraton. Geophysical Research Letters 26, 3413-3416.

Owens, T.J., Zandt, G., Taylor, S.R., 1984. Seismic evidence for an ancient rift beneath the Cumberland Plateau, Tennessee: a detailed analysis of broadband teleseismic $P$ waveforms. Journal of Geophysical Research 89, 7783-7795

Parsons, T., Zoback, M.L., 1997. Three-dimensional upper crustal velocity structure beneath San Francisco Peninsula, California. Journal of Geophysical Research 102, 5473-5490.

Patane, D., Chiarabba, C., Cocina, O., De Gori, P., Moretti, M., Boschi, E., 2002. Tomographic images and 3D earthquake locations of the seismic swarm preceding the 2001 Mt. Etna eruption: evidence for a dyke intrusion. Geophysical Research Letters 29 http://dx.doi.org/10.1029/2001GL014391.

Pevzner, R., Shulakova, V., Kepic, A., Urosevic, M., 2011. Repeatability analysis of land time-lapse seismic data: CO2CRC Otway pilot project case study. Geophysical Prospecting 59, 66-77.

Plomerová, J., Babuška, V., Kozlovskaya, E., Vecsey, L., Hyvönen, 2008. Seismic anisotropy a key to resolve fabrics of mantle lithosphere of Fennoscandia. Tectonophysics $462,125-136$.

Pratt, R.G., 1999. Seismic waveform inversion in the frequency domain, Part 1: theory and verification in a physical scale model. Geophysics 64, 888-901.

Pratt, R.G., Shipp, R.M., 1999. Seismic waveform inversion in the frequency domain, part 2: fault delineation in sediments using crosshole data. Geophysics 64, 902-914

Pratt, R.G., Worthington, M.H., 1988. The application of diffraction tomography to cross-hole seismic data. Geophysics 53, 1284-1294. 
Pratt, R.G., Song, Z.M., Williamson, P., Warner, M., 1996. Two-dimensional velocity models from wide-angle seismic data by wavefield inversion. Geophysical Journal International 124, 323-340.

Preston, C., Monea, M., Jazrawi, W., Brown, K., Whittaker, S., White, D., Law, D., Chalaturnyk, R., Rostron, B., 2005. IEA GHG Weyburn CO2 monitoring and storage project. Fuel Processing Technology 86, 1547-1568.

Priestley, K., Cipar, J., Egorkin, A., Pavlenkova, N., 1994. Upper-mantle velocity structure beneath the Siberian platform. Geophysical Journal International 118 , 369-378.

Prodehl, C., Mooney, W.D., 2012. Exploring the Earth's Crust: History and Results of Controlled-Source Seismology. The Geological Society of America, Boulder.

Rawlinson, N., Reading, A.M., Kennett, B.L.N., 2006. Lithospheric structure of Tasmania from a novel form of teleseismic tomography. Journal of Geophysical Research 111 http://dx.doi.org/10.1029/2005JB003803.

Rawlinson, N., Pozgay, S., Fishwick, S., 2010a. Seismic tomography: a window into deep Earth. Physics of the Earth and Planetary Interiors 178, 101-135.

Rawlinson, N., Tkalčić, H., Reading, A.M., 2010b. Structure of the Tasmanian lithosphere from 3-D seismic tomography. Australian Journal of Earth Sciences 57, 381-394.

Reading, A.M., Kennett, B.L.N., 2003. Lithospheric structure of the Pilbara Craton, Capricorn Orogen and northern Yilgarn craton, Western Australia, from teleseismic receiver functions. Australian Journal of Earth Sciences 50, 439-445.

Ren, Y., Shen, Y., 2008. Finite frequency tomography in southeastern Tibet: evidence for the causal relationship between mantle lithosphere delamination and the northsouth trending rifts. Journal of Geophysical Research 113, B10316 http://dx.doi.org/ 10.1029/2008JB005615.

Revenaugh, J., 1995. A scattered-wave image of subduction beneath the transverse ranges. Science 268, 1888-1892.

Rickett, J.E., Lumley, D.E., 2001. Cross-equalization data processing for time-lapse seismic reservoir monitoring: a case study from the Gulf of Mexico. Geophysics 66, 1015-1025.

Roecker, S., Baker, B., McLaughlin, J., 2010. A finite-difference algorithm for full waveform teleseismic tomography. Geophysical Journal International 181, 1017-1040.

Rondenay, S., Bostock, M.G., Shragge, J., 2001. Multiparameter two-dimensional inversion of scattered teleseismic body waves 3: application to the cascadia 1993 data set. Journal of Geophysical Research 106, 30,795-30,807.

Ryberg, T., Weber, M., 2000. Receiver function arrays: a reflection seismic approach. Geophysical Journal International 141,1-11.

Ryberg, T., Wenzel, F., Mechie, J., Egorkin, A., Fuchs, K., Solodilov, L., 1996. Two-dimensional velocity structure beneath northern Eurasia derived from the super longrange seismic profile Quartz. Bulletin of the Seismological Society of America 86, 857-867.

Salisbury, M.H., Milkereit, B., Ascough, G., Adair, R., Matthews, L., Schmitt, D.R., Mwenifumbo, J., Eaton, D.W., Wu, J., 2000. Physical properties and seismic imaging of masive sulfides. Geophysics 65, 1882-1889.

Sanders, C.O., 1993. Local earthquake tomography: attenuation - theory and results. In: Iyer, H.M., Hirahara, K. (Eds.), Seismic Tomography: Theory and Practice. Chapman \& Hall, London, pp. 676-694.

Scherbaum, F., 1987. Seismic imaging of the site response using microearthquake recordings. Part 1. Method. Bulletin of the Seismological Society of America 77, 1905-1923.

Shapiro, N.M., Campillo, M., 2004. Emergence of broadband Rayleigh waves from correlations of the ambient seismic noise. Geophysical Research Letters 31 http:// dx.doi.org/10.1029/2004GL019491.

Shapiro, N.M., Campillo, M., Stehly, L., Ritzwoller, M.H., 2005. High-resolution surface wave tomography from ambient seismic noise. Science 307, 1615-1618.

Sheehan, A.F., Shearer, P.M., Gilbert, H.J., Dueker, K.G., 2000. Seismic migration processing of P-SV converted phases for mantle discontinuity structure beneath Snake River Plain, western United States. Journal of Geophysical Research 105, 19,05519,065 .

Sheen, K.L., White, N., Caulfield, D.P., Hobbs, R.W., 2011. Estimating geostrophic shear from seismic images of oceanic structure. Journal of Atmospheric and Ocean Technology 28, 1149-1154.

Sheriff, R.E., Geldart, L.P., 1995. Exploration Seismology. Cambridge University Press, Cambridge.

Shito, A., Karato, S.-I., Matsukage, K.N., Nishibara, Y., 2006. Towards mapping the threedimensional distribution of water in the upper mantle from velocity and attenuation tomography. Earth's Deep Water Cycle. Vol. Geophysical Monograph Series, 168. American Geophysical Union, Washington, D.C., pp. 225-236.

Sirgue, L., Pratt, R.G., 2004. Efficient waveform inversion and imaging: a strategy for selecting temporal frequencies. Geophysics 69, 231-248.

Snyder, D.B., Rondenay, S., Bostock, M.G., Lockhart, G.D., 2004. Mapping the mantle lithosphere for diamond potential using teleseismic methods. Lithos 77, 859-872.

Snyder, D.B., Eaton, D.W., Hurich, C.A., 2006. Special issue - seismic probing of continents and their margins - introduction. Tectonophysics 420, 1-4.

Steck, L.K., Thurber, C.H., Fehler, M., Lutter, W.J., Roberts, P.M., Baldridge, W.S., Stafford, D.G., Sessions, R., 1998. Crust and upper mantle $P$ wave velocity structure beneath Valles caldera, New Mexico: results from the Jemez teleseismic tomography experiment. Journal of Geophysical Research 103, 24,301-24,320.
Suckale, J., Rondenay, S., Sachpazi, M., Charalampakis, M., Hosa, A., Royden, L.H., 2009 High-resolution seismic imaging of the western hellenic subduction zone using teleseismic scattered waves. Geophysical Journal International 178, 775-791.

Thurber, C.H., 1983. Earthquake locations and three-dimensional crustal structure in the Coyote Lake area, central California. Journal of Geophysical Research 88, 8226-8236

Thybo, H., Heikkinen, P., Kukkonen, I., 2011. Deep seismic probing of continental crust and mantle. Tectonophysics 508, 1-5.

Toomey, D.R., Foulger, G.R., 1989. Tomographic inversion of local earthquake data from the Hengill-Grensdalur Central Volcano Complex, Iceland. Journal of Geophysical Research 94, 17,497-17,17510.

Urosevic, M., Pevzner, R., Shulakova, V., Kepic, A., Caspari, E., Sharma, S., 2011. Seismic monitoring of $\mathrm{CO}_{2}$ injection into a depleted gas reservoir Otway Basin Pilot Project, Australia. Energy Procedia 4, 3550-3557.

VanDecar, J.C., Snieder, R., 1994. Obtaining smooth solutions to large, linear, inverse problems. Geophysics 59, 818-829.

Vinnik, L.P., 1977. Detection of waves converted from P to SV in the mantle. Physics of the Earth and Planetary Interiors 15, 39-45.

Wagner, D., Koulakov, I., Rabbel, W., Luehr, B.-G., Wittwer, A., Kopp, H., Bohm, M., Asch, G., 2007. Joint inversion of active and passive seismic data in Central Java. Geophysical Journal International 170, 923-932.

Wapenaar, K., Fokkema, J., Snieder, R., 2005. Retrieving the Green's function in an open system by cross correlation: a comparison of approaches. Journal of the Acoustical Society of America 118, 2783-2786.

White, D.J., Ansorge, J., Bodoky, T.J., Hajnal, Z., 1996. Special issue - seismic reflection probing of the continents and their margins - preface. Tectonophysics 264, VII-IX

Wilson, D., Aster, R., Ni, J., Grand, S., West, M., Gao, W., Baldridge, W.S., Semkin, S., 2005. Imaging the seismic structure of the crust and upper mantle beneath the Great Plains, Rio Grande Rift, and Colorado Plateau using receiver functions. Journal of Geophysical Research 110, B05306 http://dx.doi.org/10.1029/2004JB003492, 2005.

Xu, X., Ma, Y., Shi, D., Wang, X., Yin, C., 2009. Application of teleseismic tomography to the study of shallow structure beneath Shizigou in the western Qaidam basin. Earthquake Science 22, 189-195.

Yamauchi, M., 2003. High resolution receiver function imaging of the seismic velocity discontinuities in the crust and the uppermost mantle beneath southwest Japan. Earth, Planets and Space 55, 59-64.

Yang, Y., Ritzwoller, M.H., Levshin, A.L., Shapiro, N.M., 2007. Ambient noise Rayleigh wave tomography across Europe. Geophysical Journal International 168, 259-274.

Yang, T., Grand, S.P., Wilson, D., Guzman-Speziale, M., Gomez-Gonzalez, J., DominiguezTeyes, T., Ni, J., 2009. Seismic structure beneath the Rivera subduction zone from finite-frequency seismic tomography. Journal of Geophysical Research 114, B01302 http://dx.doi.org/10.1029/2008JB005830.

Yang, Y., Ritzwoller, M.H., Jones, C.H., 2011. Crustal structure determined from ambient noise tomography near the magmatic centers of the coso region, southeastern california. Geochemistry, Geophysics, Geosystems 12, Q02009 http://dx.doi.org/ 10.1029/2010GC003362.

Yao, H., van der Hilst, R.D., de Hoop, M.V., 2006. Surface-wave array tomography in SE Tibet from ambient seismic noise and two-station analysis - I. Phase velocity maps. Geophysical Journal International 166, 732-744.

Young, C.-H., Ward, R.W., 1980. Three-dimensional Q ${ }^{-1}$ model of the Coso Hot Springs known geothermal resource area. Journal of Geophysical Research 85, 2459-2470.

Young, M.K., Rawlinson, N., Arroucau, P., Reading, A.M., Tkalčić, H., 2011. High-frequency ambient noise tomography of southeast Australia: new constraints on Tasmania's tectonic past. Geophysical Research Letters 38, L13313 http://dx.doi.org/10.1029/ 2011 GL047971.

Zhang, H., Thurber, C., 2005. Adaptive mesh seismic tomography based on tetrahedral and Voronoi diagrams: application to Parkfield, California. Journal of Geophysical Research 110, B04303 http://dx.doi.org/10.1029/2004JB003186.

Zheng, S., Sun, X., Song, X., Yang, Y., Ritzwoller, M.H., 2008. Surface wave tomography of China from ambient seismic noise cross correlation. Geochemistry, Geophysics, Geosystems 9 http://dx.doi.org/10.1029/2008GC001981.

Zhu, L., Kanamori, H., 2000. Moho depth variation in southern California from teleseismic receiver functions. Journal of Geophysical Research 105, 2969-2980.

N. Rawlinson

Research School of Earth Sciences, The Australian National University, Canberra, ACT 0200, Australia

Corresponding author. Tel.: +6126125 5512; fax: + 61262572737 .

E-mail address: nick@rses.anu.edu.au.

B.R. Goleby

Energy Division, Geoscience Australia, GPO Box 378, Canberra, ACT 2601, Australia 